\title{
Investigation of the Role of Goal Setting Objectives and its Outcomes among Young Learners
}

\author{
Dr. Mrs. Shraddha. A. Deshpande
}

Assistant Professor and Head, Department of English, Dharampeth M. P. Deo Memorial Science College, Nagpur, India

Received: 03 Jun 2021; Received in revised form: 25 Jun 2021; Accepted: 02 Jul 2021; Available online: 9 Jul Jun 2021

(C)2021 The Author(s). Published by Infogain Publication. This is an open access article under the CC BY license (https://creativecommons.org/licenses/by/4.0/).

\begin{abstract}
Focus and direction are the primary aspects of teaching and learning when you are dealing with young learners. The age demands it; however it is observed that it is the least important task they are persuaded to. Any task of learning requires well-defined steps of goal setting that eventually transcending them to their accomplishments. At the same time, consistent efforts in the direction of their set goals are the keys to their actual success of learning. When given a choice of attempting a particular task, like joining a Language and a Literature Club, it was observed that more than average number of learners had specific goals in being a part of each clubs. The present paper aims at studying the goal setting objectives of the young learners towards the learning process. It also presents the contributions of the learners thatwere instrumental in achieving their well-defined personal and profession goals. The study is based on Edward Locke's Goal Setting Theory which postulates that people work better and harder and are motivated when they are inclined to achieve a particular target.
\end{abstract}

Keywords- Edward Locke's Goal Setting Theory, Five Principles of Goal Setting, Online Learning, moral developmental milestones for adolescents.

\section{INTRODUCTION}

Motivation is the key for task completion, then be it for employees or students. Employees need to perform to raise their incentives whereas the students need it to get that job. Therefore in order to achieve these desirable goals, one has to involve in proper planning and clear goal setting initiatives. It was in the year 1960s Edwin Locke postulated the Goal-setting theory of motivation, which emphasises on study of the impact of specific and challenging goals established on the task performance feedback. The study is essentially employee focused; nevertheless, it can also be attuned to learners involved in learning a specific task of their choice. The very core aspect of Locke's Goal Setting Theory is based on five principles of Goals and its subsequent performance that involves Clarity, Challenge, Commitment, Feedback, and Complexity. His well-researched published paper called Toward a Theory of Task Motivation and Incentive in 1968, impressed Dr. Gary Latham, who collaborated with him in producing A Theory of Goal Setting \& Task
Performance, a book that expanded the theory.According to Locke and Latham, there are five goal-setting principles that can increase the chance of success:

- Clarity: Goals should be SMART

- Challenge: Goals should be challenges that care within the reach of the performer, neither too easy nor too difficult.

- Commitment: Goals should have selfmotivation for achieving desired outcomes.

- Feedback: Consistent check on whether the set goals are heading in the right direction or not.

- Complexity: Goals if seemed complex can be redesigned by modifying allotted time and other needful criteria.

\section{Locke's Goal Setting Theory in Educational Context:}

The objectives of any learning are always well defined, time bound and focused on specific outcomes. The learners are expected to go through the syllabus in order to 
decide whether to opt for the specific learning. However, learners are not always aware of their judgment as to why they have chosen a specific course. Eventually the coursework as well as the teaching-learning process becomes an ambiguous experience for them, further declining them interest interest in the topic. Their cognitive ability weakens and learning stops. In some cases, the learners continue learning in the same manner and superficially succeed by attaining required scores and proceed with a degree. But the outcome remains the same, in reality, the learning has never occurred. In other few cases, a new course is chosen with the same approach and the journey of failure continues. Nevertheless, few of them who decide to study, understand analyses, and evaluate the process of choosing a well-defined goal, surely receive their outcome. They either refer to or are aligned to the concept of SMART goals, first written down by, "George T. Doran, a consultant and former Director of Corporate Planning for Washington Water Power Company. He in his paper, Doran provides some clarification for readers on applying the SMART acronym:

'How do you write meaningful objectives?'- that is, frame a statement of results to be achieved, Managers are confused by all the verbal from seminars, books, magazines, consultants, and so on. Let me suggest, therefore, that when it comes to writing effective objectives, corporate officers, managers, and supervisors just have to think of the acronym SMART. Ideally speaking, each corporate, department, and section objective should be: (SMART). [1]

Long before that, in 1968, Edwin A. Locke has postulated that workplace management can produce motivation that improves performance and allures incentives. He in his, ground-breaking Goal Setting Theory in collaboration with Dr. Gary Latham suggested five principles, and two main characteristics that focused not only on the primary process of goal setting but also on the efforts required to put for expected outcomes. As one can see, how the application of SMART goals have helped people from different corporate and management field to achieve their targets, the same application can also be utilized for setting goals at academic level for young learners.

\section{The objective of the study:}

- To investigate whether learners set goals before they decide to participate in a learning activity of their choice.

- To investigate how learners perform to their set goals regarding any learning activity of their choice.
- $\quad$ Learners set goals while choosing an activity of their choice.

- Learners perform better when they have set goals to participate in the activity of their choice.

\section{RESEARCH METHODOLOGY}

The research was performed in the form of an experiment to determine the decision-making capacity of adolescents to participate in a specific learning activity in the backdrop of boredom and inactivity the pandemic has created for them for more than one. An English Language Learning Club and An English Literature Club have been formed on Whatsapp and around students of Bachelor of Science of all the three years joined the groups in gusto. English Junction

This group was based on teaching the English Language that focused on teaching English from basics.

- 113 students initially joined the group and the teaching initiated with the nouns, verbs, adverbs, adjectives, and so on.

- Text and Visuals were used to explain the basic concept.

- Online discussion was carried out simultaneously to solve more examples and queries.

\section{Outcome:}

Students learned grammar and participated in solving exercises. 35 students out of 113 were active in the group. The remaining students were removed from the group. With consistent requests to re-join, the total number raised to 43 .

\section{English Literature Gateway}

The next activity was introduced as a learning platform for English Literature.

- $\quad 54$ members joined the group and were consistent in their performance.

Outcome: Students wrote their own quotes, shared poems of their choice, and wrote poems based on the video shared with them. 54 students actively participated in all the writing and reading tasks assigned to them in the stipulated time.

\section{Findings:}

\section{Clarity:}

- $64.9 \%$ of the learners agreed that they had specific goals in joining this group, remaining were unsure of it.

- $\quad$ Out of them 89.2 were self-motivated and $10.8 \%$ did not think so.

\section{Assumptions:}


- $\quad$ Purpose of joining was, $64.9 \%$ had interest, $24.3 \%$ had a passion and $10.8 \%$ had liked to join the learning activity.

- Their goals for joining this group was to learn about English Language and Literature and $(51.4 \%)$, Develop Creative Writing Skills (62.2\%), Enjoy Language and Literature (21.6\%), for professional Development $(59.5 \%)$, personal development $(35.1 \%)$

\section{Challenges:}

- $47.1 \%$ voted that they cannot write like others, $38.2 \%$ cannot write every day.

- $71.1 \%$ learners felt joining this group has motivated them, $14.3 \%$ felt had enhanced them as an artists, nevertheless, $8.6 \%$ demoralised them for their lack of creativity.

\section{Commitment:}

- $73 \%$ wanted to stay because they are learning,

- The learners were committed to staying in the group, participate in team activities $(69.4 \%)$ ask questions to raise knowledge $(19.4 \%)$, reading at least once in 2 days (11.1\%).

- Their commitment enhanced in the group by $44.4 \%$ if they are appreciated and motivated for their contribution, provided with new knowledge, $36.1 \%$ if they get the opportunity to collaborate.

\section{Feedback:}

- Feedback on the content given by the learners is as $43.2 \%$ felt it was knowledgeable and appropriate, $29.7 \%$ felt it was relevant and interesting, $27 \%$ voted it to be informative and creative.

- $\quad$ Feedback on teaching style was $56.8 \%$ interesting, $24.3 \%$ understandable and $13.5 \%$ appropriate.

- $\quad$ Feedback on the pace of the class: $83.3 \%$ appropriate, $8.3 \%$ for slow and fast.

- $\quad$ Feedback on peers: $77.8 \%$ creative, $61.1 \%$ competent, $\quad 27.8 \% \quad$ collaborative, $11.1 \%$ attidunious, $2.8 \%$ incompetent.

- $\quad$ Feedback of feedback given by the teachers, $77.8 \%$ were of the opinion it was regular, $13.9 \%$ intermittent, and $8.3 \%$ irregular.

\section{Task Complexity:}

- $82.5 \%$ of learners said that tasks were matching their goals, $10 \%$ behind their goals, and $7.5 \%$ ahead of their goals.

- $\quad$ Out of the $52.5 \%$ are achieving the deadlines and remaining, just reaching it.

- For $75 \%$ of them the assignments are appropriate, for $17 . \%$ they are easy and for rest, they seemed complex.

- The last and important question was: What if the tasks become complex in the progression of the learning? To which, $67.5 \%$ responded that they will try to learn, and the remaining would enjoy the challenges of the complex task.

\section{CONCLUSION}

The search for knowledge is a difficult task, FabiolaGianotti opined, but what to search and why to search are its pre-requisites. It is imperative to understand the purpose behind initiating a task and then also equally important is its execution. A well-defined task can procure the most expected results. The learners in the above experiment had specific objectives in their mind before joining the activity; therefore the results they got were extremely satisfactory and fruitful. The outcomes were measurable and enjoyable in the form of the creative writings of the learners. The discussions were deep and extensive, till the learning was not accomplished. Few learners were apprehensive about their participation, but self-paced learning helped them to overcome this issue as well. Also, the consistent attendance in the group was monitored that maintained the gravity of the teachinglearning process. This approach created a sense of responsibility towards the progression of their pre-defined goals. The learners had done exactly what Tony Robbins had said' "Setting goals is the first step in turning the invisible into the visible.

\section{RECOMMENDATIONS}

One of the major aspects of the National Education policy is the introduction of a multidisciplinary College in every district which emphasizes the flexibility offered to students to choose their choice of subjects. This kind of freedom gives learners a chance to critically think, self-analyse, and then commit to a particular career based on their own liking and capability. The whole process will involve a goal-setting initiative as a vital step for these inspiring aspirants, to begin with. Such a pragmatic start will ensure their smooth and encouraging academic journey which was otherwise burdened by the gamut of compulsory subjects. However one cannot go away with the problems 
of compulsory subjects in the present education system. In some cases, we can introduce a liberal approach by offering learners such activities they can enrol by choice. English Language Junction and English Literature Gateway were such platforms offered to the students of Language and Literature Learning. As the learners chose to be a part of these groups on their own, they were most benefitted, as rightly quoted by Jean-Paul Sartre "We are our choices."

\section{REFERENCES}

[1] Dotson, R. (2015). Does goal setting with elementary students impact reading growth? (Doctoral dissertation). Retrieved from ProQuest Dissertations Publishing. (Accession No. 10019493).

[2] Doran. (1981). There's a S.M.A.R.T. way to write management's goals and objectives. Management Review, 70(11), 35-36.

[3] Hwang, Y. (1995). Student apathy, lack of selfresponsibility and false self-esteem are failing American schools. Education, 115(4), 484-490.

[4] Jenkins, D. (1994). An eight-step plan for teaching responsibility. The Clearing House: A Journal of Educational Strategies, Issues and Ideas, 67(5), 269-270.

[5] Smith, E (2007). Considering the experiences of 'underachieving' and 'overachieving' student'. International Journal of Research and Method in Education. 30(1), 19-32. doi: 10.1080/17437270701207702

[6] Smith, E. (2003). 'Understanding under achievement: an investigation into the differential achievement of secondary school pupils'. British Journal of Sociology. 24(5), 575586. doi: 10.1080/0142569032000127143.

[7] https://www.projectsmart.co.uk/brief-history-of-smartgoals.php

[8] https://peakon.com/blog/employee-success/edwin-lockegoal-setting-theory/

[9] https://getlucidity.com/strategy-resources/guide-to-locke-sgoal-setting-theory/ 